\title{
Policy of Primary Health Center as First Level Health Facility for Participants of Social Health Insurance Provider Sidoarjo - Indonesia
}

\author{
Hadi Shubhan $^{1}$, Rr Herini Siti Aisyah ${ }^{1} \&$ L. Budi Kagramanto ${ }^{1}$ \\ ${ }^{1}$ Universitas Airlangga Surabaya, Indonesia \\ Correspondence: Rr Herini Siti Aisyah, Universitas Airlangga Surabaya, Indonisia. E-mail: herini@fh.unair.ac.id
}

Received: January 18, 2018

Accepted: February 23, $2018 \quad$ Online Published: June 14, 2018

doi:10.5539/ilr.v7n1p227

URL: https://doi.org/10.5539/ilr.v7n1p227

\begin{abstract}
In 2012 there were 200 cases of public service disputes to be criminalized in East Java. They occured as a logical consequence of Act Number 14 Year 2008 leading to some consequences that public service is required to give satisfaction to the society The problem of health services in Indonesia cannot be separated from the low competence of the medical personnel, infrastructure and medical equipment, human resources, and complex regulations which are not easy to implement. Due to the problem above, a research focused on such policies to improve the capacity building by optimizing the role of Primary Health Center (PHC) as First Level Health Facility (FLHF) especially for Participants Social Health Insurance Provider (SHIP) is highly considered to carry out. The Social Health Insurance Provider is a legal entity established to administer the Health Insurance program, and the Primary Health Center is a health service facility that organizes some efforts on public and individual health at the first level. In ensuring the satisfaction of adequate services, FLHF has been working with PHC as the implementer of health services for SHIP participants. Because of it, PHC becomes the forefront to provide the health services to the community, especially, to SHIP participants. To increase the satisfaction of SHIP participants, it is necessary to note and find some ways out to the problems related to the improvement of Human Resources, Health Facilities, Service system, Information and supervision.
\end{abstract}

Keywords: policy, health, service

\section{Introduction}

Improving the quality of Primary Health Facilities or Primaary Health Center ((Puskesmas/PHC, Pratama Clinic) is very important in the era of National Health Insurance (NHI); because more than $80 \%$ of health problems must be managed properly at the primary level. (https://www.facebook.com/UGM). The percentage of PHC patients referred to some hospitals is $21 \%$. The referral cases are due to the inability to handle such severe diseases and the unavailability of a laboratory facility to perform some examinations. (Lasudi 2015: 108) Based on the standards of the health service, one PHC serves 30,000 people. The number of the medical personnel at the PHC is not adequate. There are still some that do not have a pharmacist, and they are also lack of the number of doctors and nurses. In fact, the existence of non-local hospital health services is vital, especially, after the ongoing SHIP health program has been launched and the status of PHC is considered to become the first level of health service of SHIP (Jawa post-Tuesung 09 february 2016: 33) PHC is one of the public service sectors that prioritizes the fulfillment of community satisfaction through the qualified health services. (Natalya S 2014: 5)

The problems of this research are (a) How is the legislation regulating the Role of Primary Health Center In providing services as First Level Health Facility (FLHF) in order to improve health service participant BPJS? (b) What factors become the obstacles of the Primary Health Center in optimizing its role in providing services as a First Level Health Facility (FLHF) to improve the health services of BPJS participants?

In accordance with the 2012-1019 roadmap of National Health Security, the World Health Organization (WHO) states that there are three dimensions that are absolutely necessary to consider. (1) what the percentage of the population is guaranteed, (2) how complete the services are guaranteed, and (3) a direct cost projection which is still borne by the population. (Amri Yusuf, 2016) It is, therefore, very important and strategic to make some efforts to improve the optimization of the role of PHC as a First Level Health Facility (FLHF) for SHIP participants. The role of PHC is very important in the effort towards Healthy Indonesia which can be achieved through improving health services and beginning to switch the orientation of health paradigm. Curative and rehabilitative services should have a high leverage for health improvement and disease prevention for healthy 
people. The fulfillment of the need for health services should be supported by various health facilities and institutions. The provision of health facilities is jointly organized by the government and private sectors by taking into account some factors such as the poor and special groups like infants, toddlers and pregnant women (Anoname, 2013)

The purposes of this study are to find: the legal basis regulating the role of PHC as the First Level Health Facility (FLHF), the obstacles of PHC in optimizing its role in providing services as FLHF to improve Health Service for SHIP Participants, and the ideal Model Design for PHC to optimally provide services as FLHF. One of the goals of health development in Indonesia is to improve the quality of health services. It should be implemented in all public and private health services. The qualified improvement of the health services is highly expected to attract the people to be more interested in utilizing health service facilities starting from PHC, hospital and other health service facilities (Pohan I S, 2002)

\section{Library Review}

There are many aspects affecting the improvement of the quality of health service (1). Reliability. It includes the service accuracy in accordance with the uncomplicated procedures of examination services and timely service schedule; (2) Responsiveness; (3). Assurance. It covers the knowledge and skill of health of the workers about diseases, and the management of the client complaints (4). Empathy; It means that the officers pay special attention to clients; 5. Physical evidence (tangibles). It includes the cleanliness and neatness of the officers and rooms, and readiness of the tools or equipment to be used. (Nizwardi Azkha, 2007: 71) One of the dimensions that gets the highest minus score is the dimension of responsiveness in which the patients complain about the willingness of the officers in serving the patients quickly, especially to SHIP participants and Jamkesmas. (Retno Eka Pratiwi, 2013) To improve the health services, the Government can utilize the contracting out model, contract out the provision of certain types of services, for example nonclinical services (Bhisma Murti 2006: 116)

The mismanagement and the leakage of the state and local finance can be avoided. However, there are some barriers in the implementation of transparency and accountability in financial management of the local government. They are the readiness of Human Resources, the old management system which is not easily changed to the better one which could meet the demands of the people, and the political cultures in which there are less local authorities allocate the budget for the public interest. (Tatiek Sri Djatmiati, 2014:18) SHIP service mechanisms are generally divided into two: (1) emergency patient care; (2) Ordinary patient care (Filu Marwati Santoso Putri, 2014) In order to avoid the accumulation of patients, PHC service can be carried out through some methods as follows: (a). Queuing at PHC, (b). Practicing physicians, in the care range for patients to reduce the focus of primary care in PHC, (Syahdat Nurkholiq, 2011)

Related to the management of facilities and human resources in PHC and hospitals, the health services are still unable to meet the needs of the people for health referral services. Networking in the referral process is still done partially and there is no integrated communication network system at all PHCs and hospitals. (Ignasius Luti, et al, March 2012: 33). Some dissatisfactions towards the health services of SHIP occurred in the Implementation of health service (a). for SHIP patients at primary health care facilities, (b) for SHIP patients at secondary health service facilities (c). for SHIP patients in emergency cases (d). Disputes of SHIP health service in primary health service (Filu Marwati Santoso daughter 2014; 17

In the research (Hadi, 2015) suggested that it was necessary to synergize all parties involved in health services, especially related to the relationship of the central and regional governments, inter-agency relations in the region, improving the quantity, quality, and hard and soft skill competence of the apparatus, especially in health services at the primary level. The issues that often arise in the implementation of SHIP are: First, there is no transparency of the hospital management in the distribution of the SHIP packages to the health workers (doctors) and to the medications. Secondly, the government should also provide some incentives to private hospitals related to SHIP services. Thirdly, SHIP should carry out mapping to identify the densely populated and non-densely populated areas. (Okky Asokawati, 2016: 4)

Representative PHCs and Midwives in the Village within the working area of PHC are an integral part of PHC. Representative PHCs performs some of the PHC duties in accordance with the ability of the personnel and facilities available in certain areas covered in the working area of PHC. Actually, the type of PHC and the number of the personnel do not need to be the same for each PHC. Some important things that must be highly considered in the area of work are: the number of the people, the areas covered, the geographical and transportation conditions.

At the present time, however, the number of available personnel has not been able to meet the needs so 
temporarily there is a kind of equalized pattern for each PHC. The important thing is that they work in a team. It means that a staff can fill the shortcomings of the other and vice versa. Although the work is done differently, all are within the framework of one goal - it is the improvement of public health in the work area of the PHC led by the Head of PHC. (b) Technical guidance and supervision. In addition to the regular meetings with PHC staff, the Head of PHC should also come to see and give guidance to the staff regularly in their workplaces at PHC, Representative PHC, in the field and in the homes of the residents in the framework of home visits. Regularly scheduled meetings must be carried out to maintain the discipline of the staff in performing their duties. During the visit, some consultations, knowledge and skill improvement for the staff are also done to increase the quality of the referral system based on the current and reliable references. (c) Working relationships among sub-district agencies. The head of the sub-district is the coordinator of all agencies at the sub-district level, and the Head of the PHC is technically responsible for the health and administrative matters to the Head of District Health Division. There is a kind of coordination relationship betweem Camat (Chief of the district) and the Head of PHC who have the morale responsibility. A good working relationship needs to be nurtured between PHC and all agencies at the sub-district level. The Head of PHC must actively find some cooperations with any institutions in the district level.

PHC is one of the services in the the public sector that prioritizes the fulfillment of community satisfaction through qualified health services. Indonesia still faces some problems of equity and affordability of health services. It is estimated that only about $30 \%$ of the population come to have PHC services. (S. Rondonuwu 2014: 5) The type of FLHF is a factor related to the patient satisfaction of NHI. Then all types of FLHF are expected to improve the quality of service especially on the dimensions of physic (tangible), reliability, and attention (empathy) (Ni Made Widiastuti 2015: 73).

There are some various problems of service at PHC, and they are: a). the very long queue in PHC waiting room. That is why recruiting more administrative staff for registration or other activities is requried for a better service. b) Doctors on duty are always expected by inpatients and outpatients to be always ready to serve at any time. c) The operational hours for patient admissions should be open earlier. (Ahmad Rizkita Fajaruddin 2015)

\section{Research Methods}

This research must be carried out comprehensively and holistically to study the problems and to achieve the goal, and a Socio Legal qualitative approach is implemented (Afdol, 2008: 11) It takes into account the normative aspects and also the field research. It takes place in Sidoarjo regency as a buffer area of Surabaya City, the provincial capital. It is expected that results of this research can also be used as Prototype of other areas.

The main sources of information in this study are District Health Office, PHC Manager, Medical and administrative Personnel of PHC, SHIP participants, who are the patients of PHC, and SHIP as the organizer of public health insurance. The source of information is determined purposively based on the class of the rank of PHC staff while the patients are based on the SHIP membership class. Snowball technique is applied to obtain some complete, deep, and comprehensive information.

Legal Materials. Collecting some primary and secondary legal materials related to the research topic is the first imporatnt priority to do. They are obtained through literature studies, books, articles, legal journals, internet, seminar results and others. Furthermore, the primary legal materials are used to explain the legal issues that become the subject of the discussion with the starting point of the theories, concepts and principles of law as the basis of research. These collected research materials are carefully studied to obtain the essence inside them, either in the form of ideas, proposals and arguments, as well as related provisions.

In-depth interview technique is used to collect the data ( Heru Irianto, 2001). They are deep and comprehensive information which are very important for the research. After conducting in-depth interviews, the results are then discussed in Focus Group Discussion - FGD ( Bungin, 2001: 172). FGD is used to gather information from various parties directly involved related to the role of PHC. Through FGD, it is expected to obtain any information from various parties related to various laws/acts and regulations, problems faced by each party and to find some solutions together so that a more comprehensive and holistic model design can be developed.

\section{Results and Discussion}

\subsection{Social Health Insurance Provider (SHIP)}

The Presidential Regulation of the Republic of Indonesia Number 72 Year 2012 governs the National Health System (NHS). Article 1 number 2. The National Health System, hereinafter abbreviated as NHS is a health management which is organized by all components of the Indonesian nation in a mutually supportive manner to ensure the achievement of the highest public health level. Article 4 (1): NHS is carried out by the government, 
the government of the district, and / or the community. Article 4: (1) NHS is carried out by the government, regional government, and / or the public (2) NHS shall be implemented in a sustainable, systematic, directed, integrated, comprehensive, and responsive manner to any changes by maintaining the national progress, unity and resilience. Article 6: (1) The implementation of NHS is emphasized on the improvement of the behavior and the independence of the society, the health professionalism of the human resources, as well as promotive and preventive efforts without overriding curative and rehabilitative efforts. (2) The professionalism of health human resources as referred to in paragraph (1) fostered by the Minister is only for health workers and health support / supporting personnel who are involved and work and devote themselves in the effort and management of health. (3) The implementation of NHS as meant in sub-article (1) must pay attention to: a. the coverage of quality, fairness and equitability in health services; b. provision of health services in favor of the people; c. public health policies to improve and protect the public health; $d$. leadership and professionalism in health development; e. innovation or scientific and technological breakthroughs that are ethical and proven to be useful in the implementation of broader health development, including strengthening the referral systems; f. global approach by considering the systematic, sustainable, responsive health policies related to gender and child rights; g. family dynamics and population; $h$. the wishes of the society; i. epidemiology of disease; j. ecological and environmental changes; and; k. globalization, democratization and decentralization with the spirit of national unity and partnerships and cross-sectoral cooperation Article 1 of Presidential Regulation of the Republic of Indonesia Number 12 Year 2013 on Health Insurance defines that Health Insurance is a guarantee in the form of health protection so that the participants can obtain some health care benefits and protection in fulfilling the basic health needs given to every person who has already paid their contributions or has been paid by government. 2. Social Health Insurance Provider hereinafter abbreviated as SHIP is a legal entity formed to organize Health Insurance program. 3. Recipients of Health Insurance Contribution Funds hereinafter referred to as PBI Health Insurance, and they are the poor and disadvantaged persons and the participants of the Health Insurance program. 4. Participant shall be any person, including a foreigner who has worked for a minimum of 6 (six) months in Indonesia and has paid the dues. 5. Benefit is the advantage of social security which is the right of the participant and / or member of his / her family. Paragraph 14 states that Health Facility is a health service facility used to conduct individual health service efforts, which are promotive, preventive, curative or rehabilitative done by the Government, Local Government, and / or the Community.

Article 29 of the Regulation of the President of the Republic of Indonesia Number 12 Year 2013 states: (1) At the beginning, after obtaining a recommendation from the local district health office, participants are enrolled in SHIP Health at a first level Health Facility established by SHIP Health. (2) Within a period of at least 3 (three) months participants are entitled to select the desired first-level Health Facility. (3) Participants must obtain health services at the first level Health Facility where they are registered. (4) Under certain circumstances, the provisions referred to in paragraph (3) shall not apply to participants who: a. are outside the first level of the Health Facility where they are registered; or b. in a state of medical emergency. (5) In terms of the Participants require further health care, the first-level Health Facility should refer them to the nearest primary reference health facility in accordance with the referral system stipulated in the provisions of the legislation. (6) Further provisions on first-level health services and further health referral services shall be regulated by a Ministerial Regulation.

Article 35 of the Regulation of the President of the Republic of Indonesia Number 12 Year 2013 states that (1) The Government and Regional Government are responsible for the availability of Health Facilities and the provision of health services for the implementation of the Health Insurance program. (2) The Government and the Regional Government may provide any opportunities for the private sector to participate in meeting the availability of Health Facilities and the provision of health services. Provider of Health Services Article 36 are: (1) The providers of health services shall include all Health Facilities that cooperate with SHIP Health. (2) Health Facilities owned by the Government and Regional Government fulfilling the requirements shall cooperate with SHIP Health. (3) Qualified, private health facilities may cooperate with SHIP Health. (4) Cooperation as referred to in paragraphs (2) and (3) shall be implemented by entering into a written agreement. (5) The requirements as referred to in paragraphs (2) and (3) shall be regulated by a Ministerial Regulation.

\subsection{Primary Health Center as First Level Health Facility (FLHF)}

The Regulation of the Minister of Health of the Republic of Indonesia Number 75 of 2014 on Public Health Centers - Article 2 states that (1) Health development held by PHC aims to create a society : a. having healthy behaviors that include awareness, willingness and ability to lead a healthy life; $b$. being able to reach the qualified health service; c. living in a healthy environment; and, d. having the optimal health status as an individual, family, group and community. Article 3 (1) The principles of organizing PHC cover: a. health 
paradigm; b. regional accountability; c. community independence; d. equity; e. appropriate technology; and f. alignment and sustainability.

Article 7 states that in carrying out the functions referred to in Article 5 letter b, PHC is authorized to: a. provide comprehensive, sustainable and qualified basic health services; b. conduct Health Services prioritizing the promotive and preventive efforts; c. provide health services oriented to individuals, families, groups and communities; d. organize Health Services prioritizing the security and safety of the patients, officers and visitors; e. Carry out Health Services with the principle of coordination and inter-professional cooperation; f. make medical records; g. carry out recording, reporting, and evaluation and access of Health Service quality; h. carry out the improvement of the competence of Health Manpower; i. coordinate and implement the construction of first-rate health care facilities in the working areas; and, j. carry out reference screening in accordance with medical indications and Referral System.

The Social Security Administrator (SSA) is a legal entity formed to organize a social security program. The Organizer of Social Health Security (OSHS) has started operating since January 1, 2014. It is a legal entity established to organize a Health Insurance program. The Regulation of the Minister of Health of the Republic of Indonesia Number 75 of 2014 is about the Center for Public Health, hereinafter referred to as Public Health Center or PHC. It is a health service facility that organizes public and individual health efforts prioritizing promotive and preventive efforts to achieve the highest level of public health in the working area.

First Level Health Facility (FLHF) organizes individual health services in general for the purposes of observation, promotion, prevention, diagnosis, treatment or other health services (Ministry of Health, 2014b). Health care procedure in the National Health Insurance (NHI) is the service for patients carried out in stages starting from First Level Health Facility (FLHF) held by FLHF where participants are registered. FLHF of NHI participants consist of PHC, doctors, dentists, primary clinics and Class D Pratama Hospital in collaboration with SHIP Health (Ministry of Health RI, 2014b). Both general practitioners and dentists include in the first-rate health facilities in the NHI program by doing cooperation with SHIP Health and meeting the requirements already set. Public Health Center, hereinafter referred to as PHC is FLHF that organizes public and individual health efforts of the first level by prioritizing promotive and preventive efforts to achieve the highest degree of public health in the working area (Ministry of Health RI, 2014c).

\subsection{Factors Influencing the Improvement of BPJS Participant Health Services}

In overcoming various problems Primary Health Center can not be separated from the arrangements and authority in making decisions to optimize all the resources it has. In Decision of Minister of Health Number 128 / Menkes / Sk / II / 2004 Basic Policy of Public Health Center In Chapter 2 related to Basic Concept of Primary Health Center. Function of Primary Health Center as (1) Development Center of health minded development. Primary Health Center always mobilize and advocate the development of cross-sector by society and business world in work area, so that insight and support health development. In addition, the Puskesmas is active and more. Especially for health development, efforts made by Primary Health Center is to prioritize health care and disease prevention. (2) Center for community empowerment. Primary Health Center is always ready for individuals to be wasted by community leaders, families and communities, including the business community to have awareness, willingness and ability to serve themselves and the community to live healthy, active in striving for health interests including financing, and also to determine the implementation and implementation of health programs. Empowerment of individuals, families and communities is organized with conditions and situations, especially socio-cultural society. (3) first stage health service center. Primary Health Center is responsible for the operation of health services in the first level, integrated and sustainable. The things that affect the quality of service to the participants SHIP include: (a) Human Resources.Article 6 of Regulation of the Minister of Health of the Republic of Indonesia Number 75 of 2014 is on Public Health Centers. In performing the functions referred to in Article 5 letter a, PHC is authorized to: a. undertake the planning based on the analysis of public health problems and of necessary service needs; $b$. implement the improvement of the competency of the human resources of PHC; While Article 16 states that (1) Human resources of PHC consists of Health and non health personnel (Medical and non-Medical Staff). (2) The types and number of Health and non-health personnel as referred to in paragraph (1) shall be calculated based on the analysis of workload, taking into account the number of services held, the number of population and their distribution, the characteristics of the working area, the size of area of work, the availability of first level of health service, and the division of working time. (3) The type of Health Personnel referred to in paragraph (2) shall consist of at least the following: a. physician or primary care physician; b. dentist; c. nurse; d. midwife; e. public health personnel; f. environmental health worker; g. medical laboratory technologist; h. nutritionists; and i. pharmacists. (4) Non-health or non-medical personnel as referred to in paragraph (2) shall be able to support administrative activities, financial administration, information 
systems, and other operational activities in PHC. (b) Health Facility. Article 306 Regulation of the Minister of Health of the Republic of Indonesia Number 75 Year 2014 (1) Health Facilities shall ensure that hospitalized Participants receive the necessary medicines and medical consumables in accordance with medical indications. (2) Outpatient health facilities, that do not have the supporting facilities, shall build a network with the supporting Health Facilities to ensure the availability of medicines, medical consumables and required examination. Services of Medical supplies and Medical consumables. Article 32 (1) Services of Medical supplies and consumables for Participants of Health Insurance at Health Facility shall be guided by list and price of medicines and disposable medical materials stipulated by the Minister. (2) The list and price of medicines and medical consumables as referred to in paragraph (1) shall be reviewed no later than 2 (two) years. Article 33 (1): Participants who require emergency services can directly obtain services at any Health Facility. (2) Participants receiving health services at Health Facilities without any cooperation with SHIP Health should be immediately referred to the Health Facility in cooperation with SHIP Health after the emergency is resolved and the patient is transferable. Service without any Health Facility Complies Article 34 (1) In terms of in an area there is not yet a Health Facility eligible to meet the medical needs for a number of Participants, SHIP Health shall give some compensation. (2) The compensation as referred to in paragraph (1) may be: a. cash replacement; b. dispatch of health personnel; or, c. provision of certain Health Facilities. (3) The cash reimbursement as referred to in paragraph (2) letter a shall be used for the cost of health and transportation services. (4) Further provisions concerning the granting of compensation as referred to in paragraphs (1) and (2) shall be regulated by a Ministerial Regulation.(c).Referral. Referral is the delegation of authority and responsibility for the case of illness or health problems which is held in a reciprocal way, both vertically in the sense of one strata of health service to the strata of other health services and horizontally in the sense of the same means of health service. If the patient requires a referral, it has been set related in the referral procedure as stated in the fourth principle. As a first-rate health service facility, the capability of the PHC is limited. Whereas, PHC face to face with society with various health problems in which it is mandatory for PHC to develop and innovate to support the referral principles. There are two kinds of known referral to assist PHC in resolving various health problems and to improve the efficiency in accordance with the type of health efforts held by PHC, namely: (1) Individual health referral of individual health care is related to a case of illness. If a PHC is unable to cope with a particular disease case, it should refer to a more capable health facility (both horizontal and vertical). In contrast, post-hospitalized patients who require only simple outpatient care are referred to the PHC. Referral to individual health efforts is divided into three types: (a). Referral cases for diagnostic, treatment, medical surgery and other purposes. (b). Referral of material (specimen) examination for a more complete laboratory examination. Scientific references, among others, inviting more competent personnel to give some guidance to PHC workers and or to provide medical services at PHC. (2) Referral of public health. The scope of referral to public health services is a public health problem, such as extraordinary events, environmental pollution, and disasters. Referral of public health services is also made if one PHC is unable to carry out some compulsory public health efforts and development, whereas they have become the needs of the community. If a PHC is not able to cope with the public health problems, referring to the District Health Office must be done. Referral to community health efforts is divided into three types: (1). Referral of facilities and logistics, including fogging equipment lending, health laboratory equipment borrowing, audio visual equipment borrowing, drug aid, vaccines, consumables and foodstuffs. (2). Referral of staff including inviting some experts to support the investigation of extraordinary events, assistance in solving legal health problems, and prevention of health problems due to natural disasters. (3). Operational referral, i.e., fully hand over public health issues and responsibility to solve the public health problems and / or the implementation of public health efforts (e.g. Promoting some programs for School Health, Work Health, Mental Health, examination of clean water samples) to District/Municipality Health Offices. Operational referral is a compulsory when PHC is incapable.(d) Information Center. The majority of SHIP participants, who seek treatment at PHC, are poor and it is not easy for them to understand how to deal with SHIP facilities. Let alone they are mostly low educated, even the highly educated people are not easy to understand how to deal with SHIP facilities. As a new policy concerning the interests of the wider community, it is natural if there is mazy information in SHIP service. Related to the problem above, the management of complaints is regulated in the Presidential Regulation of the Republic of Indonesia Number 12 Year 2013 on Health Insurance. Article 45 (1) In terms of the Participant is not satisfied with the Health Insurance service provided by Health Facility in cooperation with SHIP Health, Participants may submit the complaints to Health Facilities and / or SHIP Health. (2) In terms of the Participants and / or the Health Facility do not get good service from SHIP Health, the complaint is to be submitted to the Minister. (3) The submission of a complaint as referred to in paragraphs (1) and (2) shall have adequate, complete handling and resolution and shall be given feedback to the submitting party. (4) Submission of complaints as referred to in paragraph (3) shall be conducted 
in accordance with the provisions of laws and regulations. Dispute Settlement: Article 46 (1): Disputes between: a. Participants and Health Facilities; b. Participants and SHIP Health; c. SHIP Health and Health Facilities; or, d. SHIP Health and Health Facilities association; settled by the deliberation or discussion involving all related parties. (2) In case the dispute can not be resolved by deliberation or discussion, it shall be settled by means of mediation or through the courts. (3) The method of dispute resolution through mediation or courts as referred to in paragraph (2) shall be conducted in accordance with the provisions of laws and regulations. (e) Supervision. Supervision is described in the Regulation of the Minister of Health of the Republic of Indonesia Number 75 of 2014 on Community Health Center Chapter IX Guidance and Supervision Article 45 (1) The Government, Provincial Government and Regency / Municipal Government as well as the health facility of referral health services owned by the Government and Regional Government shall supervise and guide the implementation of PHC in accordance with their duties and functions. (2) The Government, Provincial Government, and Regency / City Government may involve professional organizations in conducting some guidance and supervision of the implementation of PHC. (3) The guidance and supervision as referred to in paragraphs (1) and (2) shall be directed to the improvement of the service quality to the community. (4) Guidance and supervision as referred to in paragraphs (1) and (2) are in the forms of facilitation, consultation, education and training and research and development. (5) Further provisions regarding guidance and supervision as referred to in paragraphs (1) until (4) are contained in the Annex which is an integral part of this Ministerial Regulation.

\section{Conclusions and Recommendations}

Social Health Insurance Provider, hereinafter referred to as SHIP Health, is a legal entity established to organize a Health Insurance program. Based on the Regulation of the Minister of Health of the Republic of Indonesia Number 75 of 2014 it is stated that the Center for Public Health, hereinafter referred to as PHC, is a health service facility that organizes public health efforts and individual health endeavors prioritizing the promotive and preventive efforts to achieve the highest level of public health in its working area. Quality of care, especially primary health care, is often associated with the patient satisfaction. Patient satisfaction is one of the main goals achieved in the development of NHI. SHIP has been cooperating with PHC to provide a guarantee of adequate service and satisfaction to SHIP participants. PHC becomes the forefront to provide health services to the community, in this case, SHIP participants.

Factors Influencing PHC in Providing Services as First Level Health Facilities (FLHF) (1) Human Resources. Human Resources have an important role and it is necessary to improve both quantity and quality in providing maximum service.. (2) Facilities. Health facilities are a guarantee of health protection for participants to benefit health care and protection in meeting the basic health needs provided to everyone who has paid their contributions or fees paid by the government. (3) Referral. Often there is uncertainty about the fate of patients who have difficulties in getting referrals. (4) Information Center becomes important considering the SHIP is a relatively new health insurance program so that there is still a lot of confusion in the community, especially the SHIP users who are mostly the poor. (5) Supervision. Supervision is essential to ensure the effectiveness and efficiency of health services for SHIP participants.

To improve public health services, the government changed the status of Primary Health Center to Regional Public Service Agency which has more freedom to manage health center both technically and financially. Thus expected Primary Health Center will be more developed because it can use the funds in accordance with the needs and not depend on the government. Primary Health Center will be more flexible to develop Human Resources, Facilities, as well as service system and cooperation with local hospital

\section{Acknowledgements}

We would like to thank Kemenristekdikti for this research, we also say to the Rector of Airlangga University who has given us the opportunity to conduct research, thank you that is also an infinite we also thank the government that has given us the opportunity to work the same in this study.

\section{References}

Adhitya, R. (2016). Banyak faktor penyebab tingginya kasus rujukan kompas, jakarta, 26 februari.

Afdol. (2008). Pengembangan teori implementasi hukum waris islam di indoensia, pidato pengukuhan guru besar, unair, surabaya.

Anoname. (2013). Buku Pegangan Sosialisasi Jaminan Kesehatan Nasional (JKN) dalam Sistem Jaminan Sosial Nasional. Kementerian Kesehatan Republik Indonesia Kemenkes. Sistem Kesehatan Nasional. Jakarta

Asokawati, O. (2016). Meluruskan Khitah Bpjs Kesehatan, Jawa Pos, Senin 28 Maret. 
Azkha, N. (2007). Deni elnovriza, Analisis Tingkat Kepuasan Klien Terhadap Pelayanan Kesehatan Di Primary Health Center Dalam Wilayah Kota Padang Tahun. Jurnal Kesehatan Masyarakat, September.

Bungin, B. (2001). Metodologi Penelitian Sosial. Airlangga University Press, Surabaya.

Fajaruddin Ahmad Rizkita. (2015). Kepuasan Masyarakat Terhadap Pelayanan Kesehatan Pasien Pemegang Kartu Jaminan Bpjs Di Unit Pelayanan Teknis Kesehatan Puskesmas Kecamatan Bungah Kabupaten Gresik Administrasi Negara, Fakultas Ilmu Sosial, Universitas Negeri Surabaya

Ignasius luti, dkk.: jurnal kebijakan kesehatan indonesia, vol. 01, no. 1 maret 2012.

Irianto, H. et al. (2001). Metode Penelitian Kulaitatif. PT RajaGrafindo Persada, Jakarta.

Kawedar, M., \& Indah, Y. D. (2014). Risma Silviana, Iffah Normaetika. Peran Puskesmas Di Dalam Masa Jkn (Bpjs) Dan Peran Puskesmas Dengan Dokter Keluarga Pada Masa Bpjs Ke Depan, Fakultas Kesehatan Masyarakat Universitas Jember.

Lasudi. (2015). Efektivitas Pelaksanaan Jkn Oleh Bpjs Di Puskesmas Dari Sudut Pandang Pasien Kota Jayapura Program Pascasarjana Universitas Hasanuddin Makassar.

Mardiasmo. (2013). Peran APIP Daloam Pemberantasan Korupsi, Seminar Pemberdayaan Inspektorat Jenderal Kementrian Dan Lembaga Dalam Pemeberantasan Tindak Pidana Korupsi, Jakarta, 19 Nopember.

Murti, B. (2006). Contracting Out Pelayanan Kesehatan:Sebuah Alternatif Solusi Keterbatasan Kapasitas Sektor Publik Jurnal Manajemen Pelayanan Kesehatan, vol. 09, no. 3 September.

Natalya, s. (2014). Rondonuwu, ricky c. Sondakh, budi t. Ratag , Hubungan Antara Kepuasan Pasien Terhadap Kualitas Jasa Pelayanan Rawat Jalan Dengan Minat Untuk Memanfaatkan Kembali Pelayanan Kesehatan Di Puskesmas Ranotana Weru Kota Manado fakultas kesehatan masyarakat Universitas Sam Ratulangi Manado 2014.

Nurkholiq, S. (2011). Perbandingan Tingkat Kepuasan Pasien Umum Dengan Pengguna Kartu Askes Di Pelayanan Dokter Keluarga PT. Askes, Arikel Ilmiah Program Pendidikan Sarjana Kedokteran Fakultas Kedokteran Universitas Diponegoro

Peraturan menteri kesehatan republik indonesia nomor 75 tahun 2014 tentang pusat kesehatan masyarakat.

Peraturan Presiden Republik Indonesia Nomor 12 Tahun 2013 Tentang Jaminan Kesehatan.

Pohan, S. I. (2002). Jaminan mutu pelayanan kesehatan. Jakarta: penerbit buku kedokteran Kesehatan.

Pratiwi, R. E., \& Anwar, D. S. (2013). Kualitas Pelayanan Kesehatan Peserta Jamkesmas Bagian Rawat Jalan Di Puskesmas Sumbersari, Artikel Ilmiah Hasil Penelitian Ilmu Administrasi, Fakultas Ilmu Sosial Dan Ilmu Politik, Universitas Jember.

Putri Filu Marwati Santoso P. (2014). Pelaksanakan Pelayanan Kesehatan Bpjs Dalam Perspektif Sistem Jaminan Sosial Nasional (Studi Kasus Pelayanan Bpjs Di Rumah Sakit Umum Daerah Yogyakarta Magister Hukum Universitas Muhammadiyah Surakart.

Tatiek, S. D., EmanHeru, I., \& Urip, S. (2014). Transparency and Accountability in the Finance Management of the Local Government in Promoting Good Governance. IOSR Journal Of Humanities And Social Science (IOSR-JHSS), 19(9), 15-19. https://doi.org/10.9790/0837-19991519

Undang-undang republik indonesia nomor 23 tahun 2014 Peraturan presiden republik indonesia nomor 72 tahun 2012 tentangsistem kesehatan nasional.

Widiastuti, N. M. (2015). Hubungan Jenis Fasilitas Kesehatan Tingkat Pertama, Status Kepesertaan Dan Karakteristik Sosio-Demografis Dengan Tingkat Kepuasan Pasien Jaminan Kesehatan Nasional Di Kota Denpasar, Program Pascasarjana Universitas Udayana Denpasar.

\section{Copyrights}

Copyright for this article is retained by the author(s), with first publication rights granted to the journal.

This is an open-access article distributed under the terms and conditions of the Creative Commons Attribution license (http://creativecommons.org/licenses/by/4.0/). 